\title{
Supplemental Hydroxychloroquine Therapy Regulates Adipokines in Patients With Systemic Lupus Erythematosus With Stable Disease
}

Risa Wakiya ( $\square$ wakiya.risa@kagawa-u.ac.jp )

Kagawa University https://orcid.org/0000-0003-1998-548X

Kiyo Ueeda

Kagawa University: Kagawa Daigaku

Hiromi Shimada

Kagawa University: Kagawa Daigaku

Shusaku Nakashima

Kagawa University: Kagawa Daigaku

Tomohiro Kameda

Kagawa University: Kagawa Daigaku

Mai Mahmoud Fahmy Mansour

Kagawa University: Kagawa Daigaku

Mikiya Kato

Kagawa University: Kagawa Daigaku

Taichi Miyagi

Kagawa University: Kagawa Daigaku

Koichi Sugihara

Kagawa University: Kagawa Daigaku

Mao Mizusaki

Kagawa University: Kagawa Daigaku

Rina Mino

Kagawa University: Kagawa Daigaku

Norimitsu Kadowaki

Kagawa University: Kagawa Daigaku

Hiroaki Dobashi

Kagawa University: Kagawa Daigaku

Research article

Keywords: Systemic lupus erythematosus, hydroxychloroquine, adiponectin, leptin, resistin, adipokines 
Posted Date: October 26th, 2021

DOI: https://doi.org/10.21203/rs.3.rs-942050/v1

License: (c) (i) This work is licensed under a Creative Commons Attribution 4.0 International License. Read Full License 


\section{Abstract}

Background: In patients with systemic lupus erythematosus (SLE), a higher frequency of atherosclerotic lesions is associated with poor prognosis. Hydroxychloroquine (HCQ) has been reported to improve the lifespan and the prognosis of dyslipidaemia in patients with SLE, but the mechanism is unclear. We investigated the effect of supplemental HCQ treatment on the levels of serum cytokines associated with atherosclerosis in patients with stable SLE.

Methods: Patients with SLE who received supplemental HCQ and maintained low disease activity between January 2016 and September 2020 were included in this study. Disease activity was assessed by SLE disease activity index, Cutaneous Lupus Erythematous Disease Area and Severity Index and Lupus Low Disease Activity State, and serum complement titres, anti-dsDNA antibodies, serum insulin and serum cytokines (adiponectin, resistin, and leptin) were analyzed before and after HCQ treatment.

Results: Forty-one patients ( 4 males and 37 females, mean age $41.3 \pm 13.2$ years) were included. Serum adiponectin levels were significantly increased after 3 months of HCQ treatment compared to baseline, and serum resistin levels were significantly reduced. The change in serum resistin level after HCQ administration was correlated with a significant reduction in serum TNF-a, interleukin (IL)-6, IL-8, and IL1RA levels.

Conclusions: Supplemental HCQ treatment in patients with dsDNA antibodies improved lipid levels. HCQ may improve prognosis by controlling disease activity in SLE and reducing risk factors for atherosclerosis.

\section{Background}

Systemic lupus erythematosus (SLE) is a chronic multisystem autoimmune disorder of the connective tissue characterized by autoantibodies and immune complexes; remission and flares; and highly variable clinical presentation, disease course, and prognosis $[1,2]$. Renal involvement and cardiovascular disease (CVD) are important causes of mortality in SLE [2,3]. SLE is an independent risk factor for CVD due to both traditional and disease-related risk factors such as persistent disease activity, lupus nephritis (LN), the presence of antiphospholipid antibodies and the use of glucocorticoids [4,5]. Furthermore, higher frequencies of atherosclerotic risk factors, such as hypertension and dyslipidaemia, are associated with poor prognosis in SLE $[3,6]$.

Hydroxychloroquine (HCQ) is recommended for SLE treatment unless there is a clear contraindication [4]. HCQ improves skin symptoms and arthritis as well as prevents SLE flare-ups, organ damage and cardiovascular events and reduces the risk of developing neuropsychiatric lupus [2]. In addition, HCQ has a favorable effect on lipid levels [7-12] and reduces insulin resistance $[13,14]$ and the risk of thrombosis $[15,16]$. It has also been shown to increase survival in patients with SLE [16-18]. 
HCQ was first approved for the treatment of SLE in Japan in July 2015; since then, because of the reported beneficial effects of HCQ for SLE, it has been prescribed as an additional treatment for many patients with SLE in Japan according to the recommendations [4]. However, its mechanism is unclear. In this study, we investigated the effects of HCQ therapy on serum adipokine levels in patients with SLE.

\section{Methods}

\section{Patients}

This was a single-center prospective study. We enrolled subjects who were diagnosed with SLE using the Systemic Lupus Collaborating Clinics criteria [19] and who began HCQ treatment for the first time between January 2016 and March 2020. Prior to enrolment, all patients had a $\geq 3$-month history of low disease activity, defined as (i) a SELENA-SLE disease activity index (SLEDAI) score of $\leq 8$ with no activity in major organ systems, such as renal involvement, neuropsychiatric SLE, cardiopulmonary involvement and vasculitis; (ii) current treatment with prednisolone or an equivalent dose of $\leq 10 \mathrm{mg}$ per day and (iii) well-tolerated treatment with maintenance doses of other immunosuppressant. Pregnant women and patients who changed glucocorticoid doses or immunosuppressant after starting HCQ treatment were excluded from the study. We also excluded patients not currently in complete renal remission [20], regardless of LN history. Informed consent was obtained from all participants. The study was approved by the ethical committee of Kagawa University (2020-003).

\section{Treatment and outcomes}

Patients were administered oral HCQ sulfate (Plaquenil; Sanofi-Winthrop, Paris, France) continuously for at least 3 months. HCQ was administered at a dose based on the patients' ideal body weight (IBW) calculated using the modified Broca's method: $200 \mathrm{mg}$ daily for patients with IBW $<46 \mathrm{~kg}, 200$ and 400 $\mathrm{mg}$ on alternate days for IBW $\geq 46$ and $<62 \mathrm{~kg}$ and $400 \mathrm{mg}$ daily for IBW $\geq 62 \mathrm{~kg}$.

The primary outcome was change in adipokine levels after 3 months of HCQ treatment. The secondary outcome was factors associated with a change in adipokine levels.

Clinical parameters (age, sex, body mass index (BMI), immunological biomarkers, disease activity indices and skin scores) were recorded before and after HCQ treatment. Disease activity was evaluated using the SELENA-SLEDAI 2011 criteria [21] and the Lupus Low Disease Activity State criteria [22]. Cutaneous disease activity was evaluated using the Cutaneous Lupus Erythematous Disease Area and Severity Index (CLASI) [23]. Immunological activity was determined by measuring the serum levels of complement factors (C3, C4 and CH50), anti-double stranded DNA (dsDNA) antibodies and total white blood cell, lymphocyte, and platelet counts. Serum adiponectin was measured using ELISA (Human Total Adiponectin/Acrp30 Quantikine ELISA Kit; R\&D Systems, USA). In the serum, leptin and resistin levels were determined with Simple Plex, an integrated immunoassay system for rapid and sensitive detection of targeted protein antigens across multiple biological sources. Simple Plex assays consisting of a disposable microfluidic cartridge and an automated analyzer, the Ella instrument, were performed 
according to the manufacturer's instructions (Protein Simple, CA, USA). In addition, we measured the levels of serum cytokines (TNF-a, interleukin (IL)-6, IL-8, MCP-1, MIP-1a, IL-1RA and IL-2) reported to be associated with the pathogenesis of SLE using a multiplex immunoassay (Luminex Assay, R\&D Systems) and analyzed the relationship with changes in serum adipokine levels.

\section{Statistical analysis}

Normally distributed quantitative variables were expressed as mean $\pm S D$, whereas non-parametric distributions were represented as median (interquartile range (IQR) or range). Comparisons between different groups were performed using the Wilcoxon rank sum test. Immunological biomarkers and proinflammatory adipokine levels were compared using the Wilcoxon signed-rank test for non-normally distributed data. The association of adipokine levels with clinical variables and inflammatory cytokine levels was determined by correlation analyses (Pearson's correlation coefficient). All $P$-values were twosided, and a $P$-value of $<0.05$ was considered significant. The data were analyzed using JMPß 15.2.1 software (SAS Institute, Cary, NC, USA).

\section{Results}

\section{Baseline characteristics and serum levels of adipokines}

Forty-one patients ( 4 males and 37 females, with a mean age of $41.3 \pm 13.2$ years) on treatment regimens including glucocorticoids and immunosuppressive drugs other than HCQ were included. Table 1 summarizes the clinical and immunological details of the included patients with SLE. 
Table 1

Characteristics of patients with SLE enrolled in this study.

\section{Characteristics}

Female, no. (\%)

Age, years, mean $\pm S D$

Disease duration, years, mean \pm SD

$\mathrm{BMI}$

Past involvement

Renal involvement

NPSLE

Complications

APS

Dyslipidaemia

Diabetes

Hypertension

Concomitant immunosuppressive treatments

Prednisone

No. $(\%)$

Median dosage, $\mathrm{mg} /$ day (range)

Disease activity

SELENA-SLEDAl score, median (range)

Current skin involvement

CLASI activity score, median, range

CLASI damage score, median, range

Anti-dsDNA positive, no. (\%)

Anti-dsDNA, median, range

Anti-dsDNA positive means that anti-dsDNA titre increases to $>12 \mathrm{lU} / \mathrm{ml}$.

Low complement means that $\mathrm{C} 3, \mathrm{C} 4$ or $\mathrm{CH} 50$ level decreases to $<68 \mathrm{mg} / \mathrm{dl}, 12 \mathrm{mg} / \mathrm{dl}$ or $30 \mathrm{U} / \mathrm{ml}$, respectively.

APS, anti-phospholipid antibody syndrome; NPSLE, neuropsychiatric SLE; LLDAS, Lupus Low Disease Activity State.
$\mathrm{N}=41$, no. $(\%)$

$37(90)$

$41.3 \pm 13.2$

$14.9 \pm 11.3$

$22.4 \pm 3.5$

$18(44)$

$3(7)$

8 (20)

1 (2)

1 (2)

8 (20)

34 (83)

$4.5(1-10)$
24 (59)

$2.5,0-9(n=24)$

$0,0-5(n=24)$

15 (37)

$5.4,5-82.8$ 


\begin{tabular}{|c|c|}
\hline Characteristics & $N=41$, no. $(\%)$ \\
\hline Low complement, no. (\%) & $20(49)$ \\
\hline C3 (mg/dl) & $78,40-150$ \\
\hline C4 (mg/dl) & $14,2-33$ \\
\hline CH50 (U/ml) & $34.1,14-57.5$ \\
\hline White blood cells $(/ \mu \mathrm{l})$ & $5000,1460-7630$ \\
\hline Lymphocytes $(/ \mu \mathrm{l})$ & $1052,349-3304$ \\
\hline Platelets $\left(\times 10^{4} / \mu \mathrm{l}\right)$ & $20.8,6.7-32.1$ \\
\hline LLDAS & $25(61)$ \\
\hline Clinical remission on treatment & $4(10)$ \\
\hline \multicolumn{2}{|l|}{ Pro-inflammatory cytokines } \\
\hline TNF-a, pg/ml & $3.97(2.21,9.13)$ \\
\hline IL-6, pg/ml & $1.64(1.23,4.08)$ \\
\hline IL-8, pg/ml & $4.65(1.90,12.10)$ \\
\hline MCP-1, pg/ml & $216.47(151.84,293.20)$ \\
\hline VEGF-A, pg/ml & $51.64(36.50,80.39)$ \\
\hline IL-1RA, pg/ml & $674.39(463.59,1445.65)$ \\
\hline \multicolumn{2}{|l|}{ Adipokines } \\
\hline Adiponectin, $\mu \mathrm{g} / \mathrm{ml}$ & $8.86(6.11,11.72)$ \\
\hline Leptin, ng/ml & $14.27(9.07,27.35)$ \\
\hline Resistin, ng/ml & $9.11(6.16,15.35)$ \\
\hline \multicolumn{2}{|c|}{ Anti-dsDNA positive means that anti-dsDNA titre increases to $>12 \mathrm{lU} / \mathrm{ml}$. } \\
\hline \multicolumn{2}{|c|}{$\begin{array}{l}\text { Low complement means that } \mathrm{C} 3, \mathrm{C} 4 \text { or } \mathrm{CH} 50 \text { level decreases to }<68 \mathrm{mg} / \mathrm{dl}, 12 \mathrm{mg} / \mathrm{dl} \text { or } 30 \mathrm{U} / \mathrm{ml} \text {, } \\
\text { respectively. }\end{array}$} \\
\hline $\begin{array}{l}\text { APS, anti-phospholipid antibody } \\
\text { Activity State. }\end{array}$ & hiatric SLE; LLDAS, Lupus Low Disease \\
\hline
\end{tabular}

Serum leptin levels were significantly higher in patients with SLE who received glucocorticoids than in those who did not and were higher in patients with higher BMI than in those with lower $\mathrm{BMI}(P=0.0254$ and $P=0.005$, respectively; Table 2). 
Table 2

Association of adipokine levels with clinical manifestations in patients with SLE at baseline.

\begin{tabular}{|c|c|c|c|c|c|c|c|c|}
\hline Variables & & $\mathbf{N}$ & $\begin{array}{l}\text { Adiponectin } \\
(\mu \mathrm{g} / \mathrm{ml})\end{array}$ & $P$ & $\begin{array}{l}\text { Leptin } \\
\text { (ng/ml) }\end{array}$ & $P$ & $\begin{array}{l}\text { Resistin } \\
(\mathrm{ng} / \mathrm{ml})\end{array}$ & $P$ \\
\hline \multirow[t]{2}{*}{$\mathrm{BMI}>22$} & + & 20 & $\begin{array}{l}8.71(4.98 \\
12.22)\end{array}$ & 0.9273 & $\begin{array}{l}24.55 \\
(13.26 \\
35.21)\end{array}$ & $0.0055^{\star}$ & $\begin{array}{l}9.06 \\
(6.21 \\
16.11)\end{array}$ & 0.6669 \\
\hline & - & 21 & $\begin{array}{l}9.16(6.11 \\
10.72)\end{array}$ & & $\begin{array}{l}10.86 \\
(8.02, \\
16.85)\end{array}$ & & $\begin{array}{l}9.26 \\
(5.86, \\
11.86)\end{array}$ & \\
\hline \multirow[t]{2}{*}{ Glucocorticoids } & + & 34 & $\begin{array}{l}9.01(6.17 \\
11.59)\end{array}$ & 0.6154 & $\begin{array}{l}15.97 \\
(9.95 \\
30.87)\end{array}$ & $0.0254^{\star}$ & $\begin{array}{l}9.06 \\
(5.96 \\
14.27)\end{array}$ & 0.3770 \\
\hline & - & 7 & $\begin{array}{l}7.17(2.64 \\
12.13)\end{array}$ & & $\begin{array}{l}7.19 \\
(6.45 \\
16.61)\end{array}$ & & $\begin{array}{l}10.20 \\
(6.18, \\
22.08)\end{array}$ & \\
\hline \multirow[t]{2}{*}{ LLDAS or CR } & + & 29 & $\begin{array}{l}10.22(6.24 \\
12.11)\end{array}$ & 0.0688 & $\begin{array}{l}14.25 \\
(9.65, \\
28.55)\end{array}$ & 0.6161 & $\begin{array}{l}9.26 \\
(6.64, \\
15.35)\end{array}$ & 0.1561 \\
\hline & - & 12 & $\begin{array}{l}6.61(4.52, \\
8.46)\end{array}$ & & $\begin{array}{l}15.73 \\
(6.23, \\
26.95)\end{array}$ & & $\begin{array}{l}7.15 \\
(4.49 \\
16.22)\end{array}$ & \\
\hline \multirow[t]{2}{*}{$\begin{array}{l}\text { History of lupus } \\
\text { nephritis }\end{array}$} & + & 18 & $\begin{array}{l}9.78(5.84, \\
12.44)\end{array}$ & 0.2994 & $\begin{array}{l}21.00 \\
(9.95, \\
31.91)\end{array}$ & 0.1599 & $\begin{array}{l}10.06 \\
(6.23, \\
16.75)\end{array}$ & 0.3510 \\
\hline & - & 23 & $\begin{array}{l}7.17(6.10 \\
10.70)\end{array}$ & & $\begin{array}{l}14.25 \\
(7.19 \\
22.63)\end{array}$ & & $\begin{array}{l}8.81 \\
(6.06, \\
13.51)\end{array}$ & \\
\hline \multirow[t]{2}{*}{ SLEDAI > 4} & + & 12 & $\begin{array}{l}7.04(4.52 \\
10.24)\end{array}$ & 0.1827 & $\begin{array}{l}15.73 \\
(6.23, \\
26.95)\end{array}$ & 0.5961 & $\begin{array}{l}9.50 \\
(4.49 \\
19.46)\end{array}$ & 0.5569 \\
\hline & - & 29 & $\begin{array}{l}10.07(6.14 \\
12.11)\end{array}$ & & $\begin{array}{l}14.25 \\
(9.65 \\
28.55)\end{array}$ & & $\begin{array}{l}9.11 \\
(6.22, \\
14.62)\end{array}$ & \\
\hline $\begin{array}{l}\text { Anti-dsDNA } \\
\text { positive }\end{array}$ & + & 15 & $\begin{array}{l}8.86(6.31 \\
10.70)\end{array}$ & 0.7971 & $\begin{array}{l}13.07 \\
(8.92, \\
28.26)\end{array}$ & 0.6357 & $\begin{array}{l}9.11 \\
(5.50 \\
13.93)\end{array}$ & 0.7556 \\
\hline
\end{tabular}

Median (25\% quantile, $75 \%$ quantile).

$\star P<0.05$, Wilcoxon rank sum test.

BMI, body mass index; SLEDAI, SLE Disease Activity Index; LLDAS, Lupus Low Disease Activity State; CR, Clinical Remission on/without treatment; dsDNA, double-stranded DNA. 


\begin{tabular}{|c|c|c|c|c|c|c|c|c|}
\hline Variables & & $\mathbf{N}$ & $\begin{array}{l}\text { Adiponectin } \\
(\mu \mathrm{g} / \mathrm{ml})\end{array}$ & $P$ & $\begin{array}{l}\text { Leptin } \\
\text { (ng/ml) }\end{array}$ & $P$ & $\begin{array}{l}\text { Resistin } \\
\text { (ng/ml) }\end{array}$ & $P$ \\
\hline & - & 26 & $\begin{array}{l}9.04(4.73 \\
12.01)\end{array}$ & & $\begin{array}{l}14.56 \\
(9.05, \\
27.70)\end{array}$ & & $\begin{array}{l}9.14 \\
(6.19 \\
15.63)\end{array}$ & \\
\hline \multirow[t]{2}{*}{$\begin{array}{l}\text { Low } \\
\text { complement }\end{array}$} & + & 20 & $\begin{array}{l}9.54(6.46 \\
14.10)\end{array}$ & 0.1207 & $\begin{array}{l}14.34 \\
(6.53, \\
27.72)\end{array}$ & 0.3823 & $\begin{array}{l}9.04 \\
(4.89 \\
13.30)\end{array}$ & 0.2353 \\
\hline & - & 21 & $\begin{array}{l}8.75(4.01 \\
10.54)\end{array}$ & & $\begin{array}{l}14.27 \\
(9.83, \\
29.83)\end{array}$ & & $\begin{array}{l}9.11 \\
(7.20 \\
17.14\end{array}$ & \\
\hline \multicolumn{9}{|c|}{ Median (25\% quantile, $75 \%$ quantile). } \\
\hline \multicolumn{9}{|c|}{$\star P<0.05$, Wilcoxon rank sum test. } \\
\hline
\end{tabular}

Adiponectin levels were negatively correlated with complement factors $\mathrm{C} 3$ and $\mathrm{C} 4(\mathrm{r}=-0.33, P=0.0357$ and $\mathrm{r}=-0.39, P=0.01116$, respectively), whereas leptin was positively correlated with $\mathrm{C} 3$ and $\mathrm{CH} 50$ levels ( $r=-0.33, P=0.0357$ and $\mathrm{r}=-0.39, P=0.0116$, respectively). There was no significant relationship between SLEDAl and dsDNA antibodies and serum adipokine levels. These results are shown in Table 2 and Additional file 1.

\section{Serum adipokine levels after HCQ treatment}

Serum adiponectin levels significantly increased, and serum resistin levels significantly decreased 3 months after supplemental HCQ administration compared to their values at baseline. No significant changes were observed in serum leptin levels (Fig. 1).

Next, we analyzed the association between the change in adipokine levels after HCQ administration and clinical and immunological parameters. Changes in these adipokines by HCQ treatment were not associated with the presence of hypocomplementemia. However, the change in leptin level was negatively correlated with a decrease in anti-dsDNA antibodies (Additional file 2).

There was also no significant association between changes in adipokine levels and the SLEDAl score, skin involvement or renal involvement (Table 3, Additional file 2). On the other hand, serum TNF-a, IL-6 and IL-1RA levels significantly decreased 3 months after HCQ treatment compared to their levels at baseline (Additional file 3). 
Table 3

Association between clinical parameters and changes in adipokine levels.

\begin{tabular}{|c|c|c|c|c|c|c|c|c|}
\hline $\begin{array}{l}\text { Rate of change in } \\
\text { cytokines }\end{array}$ & & $\mathbf{N}$ & $\begin{array}{l}\text { Adiponectin, } \\
\%\end{array}$ & $P$ & $\begin{array}{l}\text { Leptin, } \\
\%\end{array}$ & $P$ & $\begin{array}{l}\text { Resistin, } \\
\%\end{array}$ & $P$ \\
\hline \multirow[t]{2}{*}{$\mathrm{BMI}>22$} & + & 20 & $\begin{array}{l}17.83(7.61 \\
52.76)\end{array}$ & 0.4113 & $\begin{array}{l}-4.22 \\
(-28.21 \\
8.19)\end{array}$ & 0.7764 & $\begin{array}{l}-16.97 \\
(- \\
39.42,- \\
4.02)\end{array}$ & 0.4407 \\
\hline & - & 21 & $\begin{array}{l}11.57(1.97 \\
32.18)\end{array}$ & & $\begin{array}{l}-13.92 \\
(-35.08 \\
22.45)\end{array}$ & & $\begin{array}{l}-26.05 \\
(- \\
46.38,- \\
14.46)\end{array}$ & \\
\hline \multirow[t]{2}{*}{ Glucocorticoids } & + & 34 & $\begin{array}{l}16.03(8.28 \\
47.91)\end{array}$ & 0.3960 & $\begin{array}{l}-7.50 \\
(-30.45 \\
9.53)\end{array}$ & 0.8868 & $\begin{array}{l}-20.00 \\
(- \\
43.60,- \\
3.35)\end{array}$ & 0.1651 \\
\hline & - & 7 & $\begin{array}{l}6.92(2.18 \\
47.49)\end{array}$ & & $\begin{array}{l}-6.30 \\
(-59.10 \\
44.49)\end{array}$ & & $\begin{array}{l}-34.43 \\
(- \\
49.06,- \\
20.39)\end{array}$ & \\
\hline \multirow[t]{2}{*}{$\begin{array}{l}\text { History of lupus } \\
\text { nephritis }\end{array}$} & + & 18 & $\begin{array}{l}17.83(8.15 \\
51.05)\end{array}$ & 0.3510 & $\begin{array}{l}-2.15 \\
(-29.15 \\
11.98)\end{array}$ & 0.6815 & $\begin{array}{l}-30.57 \\
(- \\
49.96,- \\
14.65)\end{array}$ & 0.0951 \\
\hline & - & 23 & $\begin{array}{l}11.34(4.13 \\
41.82)\end{array}$ & & $\begin{array}{l}-7.50 \\
(-39.05 \\
10.55)\end{array}$ & & $\begin{array}{l}-18.69 \\
(- \\
40.91,- \\
2.70)\end{array}$ & \\
\hline \multirow[t]{2}{*}{$\begin{array}{l}\text { Decrease in SLEDAl } \\
\text { score }\end{array}$} & + & 21 & $\begin{array}{l}12.10(9.89 \\
48.65)\end{array}$ & 0.5750 & $\begin{array}{l}-7.50 \\
(-34.47 \\
35.45)\end{array}$ & 0.8074 & $\begin{array}{l}-20.81 \\
(- \\
46.97,- \\
12.62)\end{array}$ & 0.3861 \\
\hline & - & 22 & $\begin{array}{l}15.37(0.95 \\
42.06)\end{array}$ & & $\begin{array}{l}-3.90 \\
(-30.99 \\
7.24)\end{array}$ & & $\begin{array}{l}-20.73 \\
(- \\
40.91,- \\
2.75)\end{array}$ & \\
\hline
\end{tabular}

9Median (25\% quantile-75\% quantile).

${ }^{* 1}$ Negative inversion of anti-dsDNA antibody means anti-dsDNA titre decreased to $<12 \mathrm{IU} / \mathrm{ml}$.

$\star^{2}$ Improvement in low complement level is defined as an increase from baseline in one or more of C3, $\mathrm{C} 4$ or $\mathrm{CH} 50$.

$\star P<0.05$, Wilcoxon rank sum test. 


\begin{tabular}{|c|c|c|c|c|c|c|c|c|}
\hline $\begin{array}{l}\text { Rate of change in } \\
\text { cytokinesq }\end{array}$ & & $\mathbf{N}$ & $\begin{array}{l}\text { Adiponectin, } \\
\%\end{array}$ & $P$ & $\begin{array}{l}\text { Leptin, } \\
\%\end{array}$ & $P$ & $\begin{array}{l}\text { Resistin, } \\
\%\end{array}$ & $P$ \\
\hline \multirow[t]{2}{*}{$\begin{array}{l}\text { Negative inversion } \\
\text { of anti-dsDNA } \\
\text { antibodies }{ }^{* 1}\end{array}$} & + & 6 & $\begin{array}{l}29.53(2.22 \\
49.15)\end{array}$ & 0.5169 & $\begin{array}{l}-11.62 \\
(-33.01 \\
2.30)\end{array}$ & 0.0677 & $\begin{array}{l}-33.41 \\
(- \\
50.78,- \\
20.82)\end{array}$ & 0.1116 \\
\hline & - & 9 & $\begin{array}{l}11.34(4.51, \\
26.96)\end{array}$ & & $\begin{array}{l}26.42 \\
(-9.20 \\
96.62)\end{array}$ & & $\begin{array}{l}-15.25 \\
(- \\
34.93,- \\
9.28)\end{array}$ & \\
\hline \multirow[t]{2}{*}{$\begin{array}{l}\text { Improvement in low } \\
\text { complement level*2 }\end{array}$} & + & 10 & $\begin{array}{l}20.49 \\
(10.10 \\
43.82)\end{array}$ & 0.2413 & $\begin{array}{l}-7.91 \\
(-31.43 \\
8.36)\end{array}$ & 0.6232 & $\begin{array}{l}-25.65 \\
(- \\
38.64,- \\
3.48)\end{array}$ & 0.4274 \\
\hline & - & 10 & $\begin{array}{l}11.88(3.54 \\
18.80)\end{array}$ & & $\begin{array}{l}-5.10 \\
(-31.06 \\
65.33)\end{array}$ & & $\begin{array}{l}-32.49 \\
(- \\
48.69,- \\
5.69)\end{array}$ & \\
\hline \multicolumn{9}{|c|}{ 9Median (25\% quantile-75\% quantile). } \\
\hline \multicolumn{9}{|c|}{$\star^{* 1}$ Negative inversion of anti-dsDNA antibody means anti-dsDNA titre decreased to $<12 \mathrm{IU} / \mathrm{ml}$. } \\
\hline \multicolumn{9}{|c|}{$\begin{array}{l}\star^{2} \text { Improvement in low complement level is defined as an increase from baseline in one or more of C3, } \\
\text { C4 or CH50. }\end{array}$} \\
\hline \multicolumn{9}{|c|}{$\star P<0.05$, Wilcoxon rank sum test. } \\
\hline
\end{tabular}

Among the adipokines, the change in serum resistin level after HCQ was correlated with a significant reduction in serum TNF-a, IL-6, IL-8, and IL-1RA levels (Table 4). However, the increase in adiponectin and leptin levels was not correlated with a change in the levels of these cytokines (Table 4).

Table 4

Association between changes in pro-inflammatory cytokines and changes in adipokine levels.

\begin{tabular}{|lllllll|}
\hline Cytokine & \multicolumn{2}{l}{ Adiponectin $(\mu \mathrm{g} / \mathrm{ml})$} & \multicolumn{2}{ll}{ Leptin $(\mathrm{ng} / \mathrm{ml})$} & \multicolumn{2}{l|}{ Resistin $(\mathrm{ng} / \mathrm{ml})$} \\
\hline & $\mathrm{r}$ & $P$ & $\mathrm{r}$ & $P$ & $\mathrm{r}$ & $P$ \\
\hline TNF-a & -0.1405 & 0.4209 & -0.3456 & 0.0453 & 0.3887 & $0.0231^{*}$ \\
\hline IL-6 & -0.1284 & 0.4237 & -0.1285 & 0.4295 & 0.3810 & $0.0153^{\star}$ \\
\hline IL-8 & -0.1586 & 0.3415 & -0.2542 & 0.1289 & 0.5438 & $0.0005^{\star}$ \\
\hline MCP-1 & 0.0483 & 0.7642 & -0.0090 & 0.9558 & 0.2061 & 0.2021 \\
VEGF-A & -0.2585 & 0.1172 & -0.2568 & 0.1250 & 0.2844 & 0.0880 \\
\hline IL-1RA & -0.0602 & 0.7086 & -0.0840 & 0.6064 & 0.8893 & $<0.0001^{*}$ \\
\hline
\end{tabular}


The correlation between the rate of changes in pro-inflammatory cytokines and the rate of changes in adipokine levels was analysed using univariate analysis.

*Data were considered significant at $P<0.05$.

Pearson's correlation coefficient ( $r$ ) was used to compute the correlations between variables.

\section{Discussion}

Adipose tissue inflammation is associated with insulin resistance and lower production of adiponectin. Wasko et al. found that HCQ improves both beta-cell function and insulin sensitivity in healthy subjects [13]. HCQ significantly increased adiponectin levels, indicating a possible anti-inflammatory effect in adipose tissue. Adiponectin has been shown to influence insulin sensitivity [24-26], and the mechanism by which HCQ affects insulin sensitivity is thought to be via the modulation of adipose tissue inflammation and adiponectin production [27-29].

In patients with SLE, increased serum adiponectin, leptin and resistin levels have been reported compared with healthy subjects [30-34], but several reports showed no difference. Therefore, there is no consensus on whether adipokines are elevated in SLE [35-39]. However, it has been reported that serum adiponectin and serum resistin as well as urinary adiponectin levels are elevated in patients with SLE with renal involvement compared to those without renal involvement [30,31, 33, 40,41]. These findings indicate that adiponectin and resistin are useful markers associated with LN. In this study, there was no significant difference in adipokine levels between patients with and without preexisting renal involvement. Since only patients with $L N$ who were in remission were included in this study, no significant difference in serum adipokine levels was observed between patients with LN and those without LN.

The relationship between adipokines and disease activity in patients with SLE other than in those with LN has also been reported in several studies. In addition, serum adiponectin levels have been positively correlated with disease activity and negatively correlated with serum C3 levels [33, 35]. Additionally, serum leptin levels were negatively correlated with disease activity and anti-dsDNA antibodies and positively correlated with hypocomplementemia [35]. In this study, we also showed an association between adiponectin or leptin and complement factors as in previous reports. On the other hand, there are reports that there is no association between SLE disease activity and adipokines [30, 33].

Resistin is an inflammatory regulator that acts downstream of inflammation [42, 43]. Upon stimulation with resistin, macrophage cells, peripheral blood mononuclear cells and hepatic stellate cells increase the release of TNF- $a$, IL-6, IL-1 $\beta$, IL-12, IL-8 and MCP-1 via NF-KB [44-48], which promotes an inflammatory response. However, several endogenous substances, such as proinflammatory cytokines, also upregulate resistin expression $[42,45,46,48]$. Thus, resistin and proinflammatory cytokines are related, and circulating resistin levels are positively correlated with proinflammatory cytokines such as CRP, TNF-a and IL-6 in type 2 diabetes, rheumatoid arthritis, chronic kidney disease, sepsis and coronary atherosclerosis $[49,50]$. In SLE, a correlation between serum resistin level and serum TNF- $a$ and IL-6 levels has been 
demonstrated $[39,51]$, but reports are scarce and the relationship between cytokines and resistin in SLE needs to be thoroughly investigated.

HCQ blocks the processing and assembly of self-peptides into complexes with major histocompatibility complex class II proteins by increasing the $\mathrm{pH}$ within intracellular vacuoles [52]. As a result, HCQ interferes with lysosomes and autophagy and inhibits the production of proinflammatory cytokines, including type I interferon, by inhibiting the Toll-like receptor (TLR)7 and TLR9 signaling pathways and the activity of cyclic GMP-AMP synthase $[53,54]$.

In this study, we found a positive correlation between the HCQ-induced decrease in resistin and a decrease in TNF-a, IL6, IL-8, and IL-1RA. This suggests that the suppression of proinflammatory cytokines by HCQ may decrease serum resistin. However, since no association was found between HCQ-induced changes in adipokine levels and changes in SLE disease activity in this study, we could not determine that SLE disease activity is related to changes in adipokine levels. It is also possible that improvement in insulin resistance decreases resistin, as reported for adiponectin in healthy subjects $[13,14]$. Ahmed et al. reported that HCQ improves glucose homeostasis in high-fat diet-induced insulin resistance, which is accompanied by a correction in the adipokine imbalance and an alleviation of insulin resistance-induced endothelial dysfunction [55]. Qatanani et al. reported that in transgenic mice expressing human resistin, inflammation of adipose tissue is promoted, lipolysis is enhanced and free fatty acids are accumulated, resulting in increased insulin resistance [56]. This could indicate that a decrease in resistin improved insulin resistance, but the mechanism of how HCQ impacts adipokine levels is not fully understood, and further research is needed.

Persistent disease activity, LN, the presence of antiphospholipid antibodies and glucocorticoid use may be risk factors for CVD in SLE [3, 4], but none were associated with HCQ-induced increases in adiponectin levels in the current study. This indicates that supplemental HCQ improved adipokine levels independent of cardiovascular risk factors and steroid-reducing effects. This effect on adipokines may contribute to the beneficial effects of HCQ on atherosclerosis [7-11] and life expectancy [16-18].

This study has some limitations. First, we excluded patients whose disease activity was improved by HCQ by excluding patients from the analysis who had reduced their glucocorticoid dose within 3 months of HCQ administration, which may have resulted in selection bias. Second, we did not monitor adherence by measuring blood HCQ levels. Third, the sample size was small. Finally, we did not include a healthy control group in this study. Nevertheless, our study has the advantage that, to the best of our knowledge, it is the first to show an effect of HCQ on adiponectin and resistin levels in patients with SLE.

\section{Conclusions}

In conclusion, we found that add-on treatment with HCQ modulated serum adipokine levels in patients with SLE. Our results suggest that supplemental treatment with HCQ may improve atherosclerosis by modulating adipokines in patients with SLE and improve their prognosis. 


\section{Abbreviations}

systemic lupus erythematosus; SLE, Hydroxychloroquine; HCQ, interleukin; IL, cardiovascular disease; CVD, lupus nephritis; LN, systemic lupus erythematosus disease activity index; SLEDAl, body mass index; BMI, Cutaneous Lupus Erythematous Disease Area and Severity Index; CLASI, anti-double stranded DNA; dsDNA, interquartile range; IQR, Toll-like receptor; TLR

\section{Declarations}

\section{Ethics approval and consent to participate}

This study was approved by the ethical committee of Kagawa University (Heisei30-047) and was prospectively registered. All participants gave written informed consent prior to entering the study. The study was conducted in accordance with the Declaration of Helsinki.

\section{Consent for publication}

Not applicable.

\section{Availability of data and materials}

The dataset supporting the conclusions of this article is available upon reasonable request.

\section{Competing interests}

The authors declare no conflicts of interest.

\section{Funding}

The authors received no financial support for the research, authorship, and/or publication of this article.

\section{Authors' contributions}

All authors were involved in drafting the article or revising it critically for important intellectual content, and all authors approved the final version to be submitted for publication. RW and HD planned the study and wrote the manuscript. RW conducted the study and interpreted the results together with $\mathrm{KU}, \mathrm{SN}, \mathrm{HS}$, TK, MK, TM, KS, MM, RM, and HD. MMFM and NK reviewed the manuscript for intellectual content. The authors read and approved the final manuscript.

\section{Acknowledgements}

We thank Anne M. O'Rourke from the Edanz Group (https://en-author-services.edanzgroup.com/ac) for editing a draft of this manuscript.

\section{References}


1. Murphy G, Lisnevskaia L, Isenberg D. Systemic lupus erythematosus and other autoimmune rheumatic diseases: challenges to treatment. Lancet. 2013;382:809-18.

2. Fava A, Petri M. Systemic lupus erythematosus: diagnosis and clinical management. J Autoimmun. 2019;96:1-13.

3. Mosca M, Tani C, Aringer M, Bombardieri S, Boumpas D, Brey R, et al. European League Against Rheumatism recommendations for monitoring patients with systemic lupus erythematosus in clinical practice and in observational studies. Ann Rheum Dis. 2010;69:1269-74.

4. Fanouriakis A, Kostopoulou M, Alunno A, Aringer M, Bajema I, Boletis JN, et al. 2019 update of the EULAR recommendations for the management of systemic lupus erythematosus. Ann Rheum Dis. 2019;78:736-45.

5. Durcan L, Winegar DA, Connelly MA, Otvos JD, Magder LS, Petri M. Longitudinal evaluation of lipoprotein parameters in systemic lupus erythematosus reveals adverse changes with disease activity and prednisone and more favorable profiles with hydroxychloroquine therapy. J Rheumatol. 2016;43:745-50.

6. Katz G, Smilowitz NR, Blazer A, Clancy R, Buyon JP, Berger JS. Systemic lupus erythematosus and increased prevalence of atherosclerotic cardiovascular disease in hospitalized patients. Mayo Clin Proc. 2019;94:1436-43.

7. Babary H, Liu X, Ayatollahi Y, Chen XP, Doo L, Uppaluru LK, et al. Favorable effects of hydroxychloroquine on serum low density lipid in patients with systemic lupus erythematosus: a systematic review and meta-analysis. Int J Rheum Dis. 2018;21:84-92.

8. Petri M, Lakatta C, Magder L, Goldman D. Effect of prednisone and hydroxychloroquine on coronary artery disease risk factors in systemic lupus erythematosus: a longitudinal data analysis. Am J Med. 1994;96:254-9.

9. Babary H, Liu X, Ayatollahi Y, Chen XP, Doo L, Uppaluru LK, et al. Favorable effects of hydroxychloroquine on serum low density lipid in patients with systemic lupus erythematosus: a systematic review and meta-analysis. Int J Rheum Dis. 2018;21:84-92.

10. Yang DH, Leong PY, Sia SK, Wang YH, Wei JC. Long-term hydroxychloroquine therapy and risk of coronary artery disease in patients with systemic lupus erythematosus. J Clin Med. 2019;8:796.

11. Rempenault C, Combe B, Barnetche T, Gaujoux-Viala C, Lukas C, Morel J, et al. Metabolic and cardiovascular benefits of hydroxychloroquine in patients with rheumatoid arthritis: a systematic review and meta-analysis. Ann Rheum Dis. 2018;77:98-103.

12. Cairoli E, Rebella M, Danese N, Garra V, Borba EF. Hydroxychloroquine reduces low-density lipoprotein cholesterol levels in systemic lupus erythematosus: a longitudinal evaluation of the lipid-lowering effect. Lupus. 2012;21:1178-82.

13. Wasko MCM, McClure CK, Kelsey SF, Huber K, Orchard T, Toledo FGS. Antidiabetogenic effects of hydroxychloroquine on insulin sensitivity and beta cell function: a randomised trial. Diabetologia. 2015;58:2336-43. 
14. Toledo FGS, Miller RG, Helbling NL, Zhang Y, DeLany JP. The effects of hydroxychloroquine on insulin sensitivity, insulin clearance and inflammation in insulin-resistant adults: a randomized trial. Diabetes Obes Metab. 2021;23:1252-61.

15. Petri M. Thrombosis and systemic lupus erythematosus: the Hopkins Lupus Cohort perspective. Scand J Rheumatol. 1996;25:191-3.

16. Ruiz-Irastorza G, Egurbide M-V, Pijoan J-I, Garmendia M, Villar I, Martinez-Berriotxoa A, Erdozain J-G, Aguirre C. Effect of antimalarials on thrombosis and survival in patients with systemic lupus erythematosus. Lupus. 2006;15:577-83.

17. Alarcón GS, McGwin G, Bertoli AM, Fessler BJ, Calvo-Alén J, Bastian HM, et al. Effect of hydroxychloroquine on the survival of patients with systemic lupus erythematosus: data from LUMINA, a multiethnic US cohort (LUMINA L). Ann Rheum Dis. 2007;66:1168-72.

18. Mok CC, Tse SM, Chan KL, Ho LY. Effect of immunosuppressive therapies on survival of systemic lupus erythematosus: a propensity score analysis of a longitudinal cohort. Lupus. 2018;27:722-7.

19. Petri M, Orbai AM, Alarcón GS, Gordon C, Merrill JT, Fortin PR, et al. Derivation and validation of the Systemic Lupus International Collaborating Clinics classification criteria for systemic lupus erythematosus. Arthritis Rheum. 2012;64:2677-86.

20. Bertsias GK, Tektonidou M, Amoura Z, Aringer M, Bajema I, Berden JH, et al. Joint European League Against Rheumatism and European Renal Association-European Dialysis and Transplant Association (EULAR/ERA-EDTA) recommendations for the management of adult and paediatric lupus nephritis. Ann Rheum Dis. 2012;71:1771-82.

21. Petri M, Kim MY, Kalunian KC, Grossman J, Hahn BH, Sammaritano LR, et al. Combined oral contraceptives in women with systemic lupus erythematosus. N Engl J Med. 2005;353:2550-8.

22. Petri M, Magder LS. Comparison of remission and lupus low disease activity state in damage prevention in a United States systemic lupus erythematosus cohort. Arthritis Rheumatol. 2018;70:1790-5.

23. Albrecht J, Taylor L, Berlin JA, Dulay S, Ang G, Fakharzadeh S, et al. The CLASI (Cutaneous Lupus Erythematosus Disease Area and Severity Index): an outcome instrument for cutaneous lupus erythematosus. J Invest Dermatol. 2005;125:889-94.

24. Ye R, Scherer PE. Adiponectin, driver or passenger on the road to insulin sensitivity? Molecular metabolism. 2013;2:133-41.

25. Li X, Zhang D, Vatner DF, Goedeke L, Hirabara SM, Zhang Y, et al. Mechanisms by which adiponectin reverses high fat diet-induced insulin resistance in mice. Proc Natl Acad Sci U S A. 2020;117:3258493.

26. Ahlstrom P, Rai E, Chakma S, Cho HH, Rengasamy P, Sweeney G. Adiponectin improves insulin sensitivity via activation of autophagic flux. J Mol Endocrinol. 2017;59:339-50.

27. Qiao X, Zhou ZC, Niu R, Su YT, Sun Y, Liu HL, et al. Hydroxychloroquine improves obesity-associated insulin resistance and hepatic steatosis by regulating lipid metabolism. Front Pharmacol. 2019;10:855. 
28. McGill JB, Johnson M, Hurst S, Cade WT, Yarasheski KE, Ostlund RE, et al. Low dose chloroquine decreases insulin resistance in human metabolic syndrome but does not reduce carotid intima-media thickness. Diabetol Metab Syndr. 2019;11:61.

29. Smith GD, Amos TA, Mahler R, Peters TJ. Effect of chloroquine on insulin and glucose homoeostasis in normal subjects and patients with non-insulin-dependent diabetes mellitus. BMJ. 1987;294:465-7.

30. Gamez-Nava JI, Diaz-Rizo V, Perez-Guerrero EE, Muñoz-Valle JF, Saldaña-Cruz AM, Fajardo-Robledo NS, et al. Assessment of serum macrophage migration inhibitory factor (MIF), adiponectin, and other adipokines as potential markers of proteinuria and renal dysfunction in lupus nephritis: a crosssectional study. Biomark Res. 2020;8:55.

31. Hutcheson J, Ye Y, Han J, Arriens C, Saxena R, Li QZ, et al. Resistin as a potential marker of renal disease in lupus nephritis: an adipokine marker in lupus nephritis. Clin Exp Immunol. 2015;179:43543.

32. Chen $H$, Shi B, Feng X, Kong W, Chen W, Geng L, et al. Leptin and neutrophil-activating peptide 2 promote Mesenchymal stem cell senescence through activation of the phosphatidylinositol 3kinase/Akt pathway in patients with systemic lupus Erythematosus. Arthritis Rheumatol. 2015;67:2383-93.

33. Diaz-Rizo V, Bonilla-Lara D, Gonzalez-Lopez L, Sanchez-Mosco D, Fajardo-Robledo NS, Perez-Guerrero EE, et al. Serum levels of adiponectin and leptin as biomarkers of proteinuria in lupus nephritis. PLOS ONE. 2017;12:e0184056.

34. Dini AA, Wang P, Ye DQ. Serum adiponectin levels in patients with systemic lupus erythematosus: a meta-analysis. J Clin Rheumatol. 2017;23:361-7.

35. Chougule D, Nadkar M, Venkataraman K, Rajadhyaksha A, Hase N, Jamale T, et al. Adipokine interactions promote the pathogenesis of systemic lupus erythematosus. Cytokine. 2018;111:20-7.

36. Huang Q, Tao SS, Zhang YJ, Zhang C, Li LJ, Zhao W, et al. Serum resistin levels in patients with rheumatoid arthritis and systemic lupus erythematosus: a meta-analysis. Clin Rheumatol. 2015;34:1713-20.

37. Sanctis JB, Zabaleta M, Biano NE, Garmendia JV, Rivas L. Serum adipokine levels in patients with systemic lupus erythematosus. Autoimmunity. 2009;42:272-4.

38. Barbosa VS, Francescantônio PL, Silva NA. Leptin and adiponectin in patients. with systemic lupus. erythematosus: clinical and laboratory correlations. Rev Bras Reumatol. 2015;55:140-5.

39. Almehed K, d'Elia HF, Bokarewa M, Carlsten H. Role of resistin as a marker of inflammation in systemic lupus erythematosus. Arthritis Res Ther. 2008;10:R15.

40. Yan C, Yu L, Zhang XL, Shang JJ, Ren J, Fan J, et al. Cytokine profiling in Chinese SLE patients: correlations with renal dysfunction. J Immunol Res. 2020:8146502.

41. Soliman S, Mohan C. Lupus nephritis biomarkers. Clin Immunol. 2017;185:10-20.

42. Filkova M, Haluzık M, Gay S, Senolt L. The role of resistin as a regulator of inflammation: implications for various human pathologies. Clin Immunol. 2009;133:157-70. 
43. Tripathi D, Kant S, Pandey S, Ehtesham NZ. Resistin in metabolism, inflammation, and disease. FEBS J. 2020;287:3141-9.

44. Atawia RT, Bunch KL, Toque HA, Caldwell RB, Caldwell RW. Mechanisms of obesity-induced metabolic and vascular dysfunctions. Front Biosci (Landmark Ed). 2019;24:890-934.

45. Bokarewa M, Nagaev I, Dahlberg L, Smith U, Tarkowski A. Resistin, an adipokine with potent proinflammatory properties. J Immunol. 2005;174:5789-95.

46. Pang SS, Le YY. Role of resistin in inflammation and inflammation-related diseases. Cell Mol Immunol. 2006;3:29-34.

47. Park HK, Kwak MK, Kim HJ, Ahima RS. Linking resistin, inflammation, and cardiometabolic diseases. Korean J Intern Med. 2017;32:239-47.

48. Acquarone E, Monacelli F, Borghi R, Nencioni A, Odetti P. Resistin: a reappraisal. Mech Ageing Dev. 2019;178:46-63.

49. Park HK, Ahima RS. Resistin in rodents and humans. Diabetes Metab J. 2013;37:404-14.

50. Vuolteenaho K, Tuure L, Nieminen R, Laasonen L, Leirisalo-Repo M, Moilanen E, et al. Pretreatment resistin levels are associated with erosive disease in early rheumatoid arthritis treated with diseasemodifying anti-rheumatic drugs and infliximab. Scand J Rheumatol. 2021;15:1-6.

51. Santos FMM, Telles RW, Lanna CCD, Teixeira AL, Miranda AS, Rocha NP, et al. Adipokines, tumor necrosis factor and its receptors in female patients with systemic lupus erythematosus. Lupus. 2017;26:10-6.

52. Fox RI. Mechanism of action of hydroxychloroquine as an antirheumatic drug. Semin Arthritis Rheum. 1993;23:82-91.

53. Schrezenmeier E, Dörner T. Mechanisms of action of hydroxychloroquine and chloroquine: implications for rheumatology. Nat Rev Rheumatol. 2020;16:155-66.

54. Kuznik A, Bencina M, Svajger U, Jeras M, Rozman B, Jerala R. Mechanism of endosomal TLR inhibition by antimalarial drugs and imidazoquinolines. J Immunol. 2011;186:4794-804.

55. Abdel-Hamid AA, Firgany AE. Favorable outcomes of hydroxychloroquine in insulin resistance may be accomplished by adjustment of the endothelial dysfunction as well as the skewed balance of adipokines. Acta Histochem. 2016;118:560-73.

56. Qatanani M, Szwergold NR, Greaves DR, Ahima RS, Lazar MA. Macrophage-derived human resistin exacerbates adipose tissue inflammation and insulin resistance in mice. J Clin Invest. 2009;119:531-9.

\section{Figures}



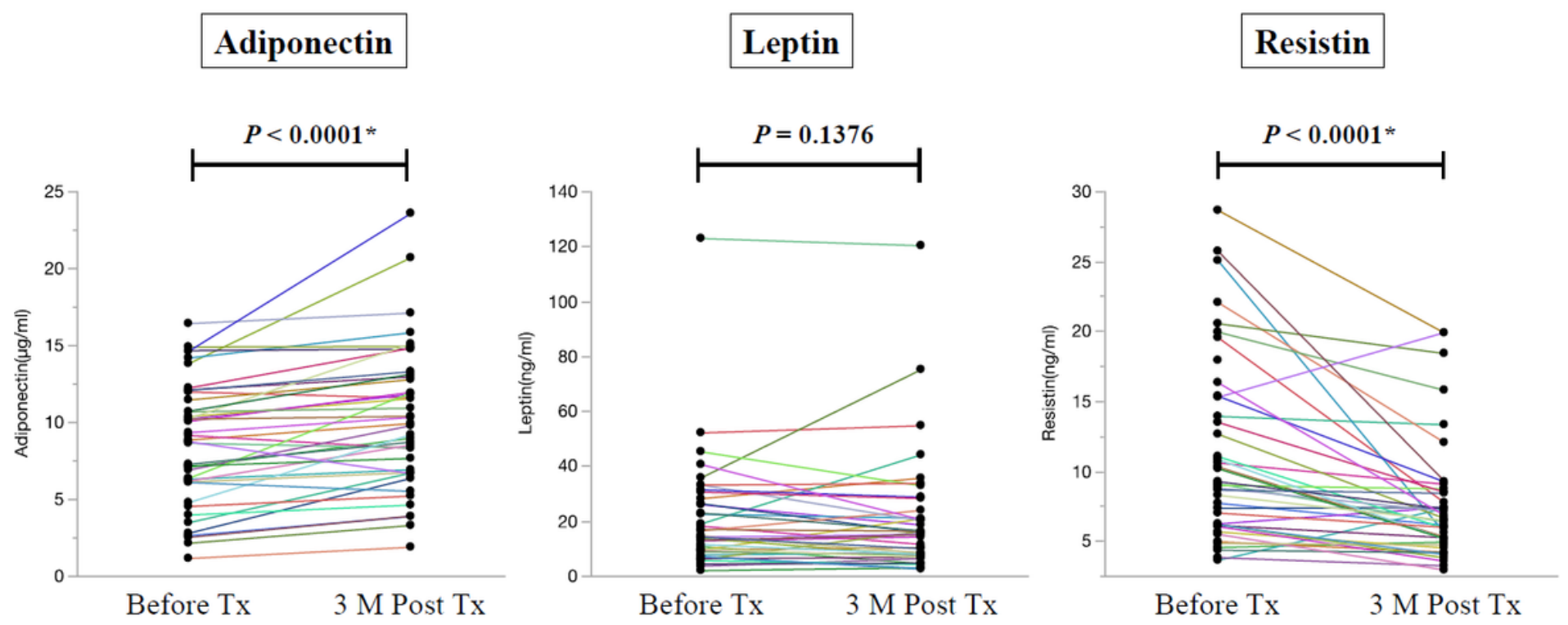

Figure 1

Serum adipokine levels before and after hydroxychloroquine treatment. Serum levels of the indicated adipokines and factors were measured before or after 3 months (3M Post) treatment ( $T x$ ) with hydroxychloroquine. Colored lines represent individual patients. NS: not significant. * indicates a P-value of less than 0.05. P-values were determined by the Wilcoxon signed-rank test.

\section{Supplementary Files}

This is a list of supplementary files associated with this preprint. Click to download.

- Additionalfile12.docx

- renamed120e1.pptx 